\title{
A Rare Cause of Adrenal Mass: Adrenocortical Oncocytoma
}

\section{Adrenal Kitlenin Nadir Bir Nedeni; Adrenokortikal Onkositom}

\author{
(D) Serdar Aslan1, (1) Mehmet Selim Nural2 \\ 1 Giresun University Faculty of Medicine, Department of Radiology, Giresun, Turkiye \\ 2Ondokuz Mayıs University Faculty of Medicine, Department of Radiology, Samsun, Turkiye
}

\begin{abstract}
Adrenocortical oncocytomas are extremely rare, usually incidentally detected tumors that are thought to have low malignant potential. The number of reported cases in the literature is below 200. These tumors are frequently non-functional and do not secrete hormones, but cases of oncocytoma causing hypertension, Cushing syndrome, and virilization have also been reported. Imaging methods are insufficient for diagnosis, and a definitive diagnosis can only be made after a histopathological examination of the adrenalectomy specimen. Here, we present the imaging and histopathological features of an adrenal mass in a 46-year-old woman who presented with left renal colic.
\end{abstract}

Keywords: Adrenal gland, Adrenal oncocystoma, Computed tomography

$\ddot{0} z$

Adrenokortikal onkositomlar son derece nadir görülen, genellikle tesadüfen saptanan ve düşük malign potansiyele sahip olduğu düşünülen tümörlerdir. Literatürde şimdiye kadar bildirilen olgu sayısı 200'ün altındadır. Sıklıkla non-fonksiyone olup hormon salgılamazlar ancak literatürde hipertansiyona, Cushing sendromuna ve virilizasyona neden olan onkositoma olguları da bildirilmektedir. Görüntüleme yöntemleri tanıda yetersiz kalmaktadır, kesin tanı adrenalektomi sonrasında yapılan histopatolojik incelemede onkositlerin gözlemlenmesi ile koyulabilir. Biz burada, sol renal kolik ile başvuran 46 yaşındaki kadın hastada saptadığımız adrenal kitlenin görüntüleme ve histopatolojik özelliklerini sunmayı amaçladık.

Anahtar Kelimeler: Adrenal gland, Adrenal onkositoma, Bilgisayarlı tomografi

\section{Introduction}

Adrenal incidentaloma refers to an asymptomatic adrenal tumor in one or both of the adrenal glands detected on a imaging test. Adrenocortical adenomas are the most common cause of incidentalomas, but cysts, myelolipomas, hematoma, pheochromocytomas, and, rarely, adrenocortical carcinomas are among the other possible causes (1). Adrenocortical oncocytoma (AO) is a very rare cause of adrenal incidentaloma. AO was first described by Kakimoto et al. (2) in 1986 and nearly 160 cases have been reported in the literature so far. AOs are typically considered non-functional and benign tumors, but in recent studies, it has been reported that $20 \%$ of AOs had malignancy characteristics and about 25\%-30\% were associated with excessive secretion of adrenal hormones (3).
AOs often appear as adrenal masses. Large-sized $(>4-5 \mathrm{~cm})$ adrenal lesions suggest malignancy, but it is known that most malignant adrenal masses cannot be distinguished by radiological imaging methods. In addition, imaging methods cannot determine if the $\mathrm{A} 0$ is benign or malign (4). This situation makes surgical excision inevitable when a large adrenal mass is encountered. The traditional surgical approach to these masses is open adrenalectomy, however, recent advances in laparoscopic techniques have made it possible to use minimally invasive methods for the resection of adrenal masses.

Here, we aimed to present the imaging and histopathological features of $A 0$ in a 46-year-old woman who presented with left renal colic. Histopathological examination performed after laparoscopic adrenalectomy confirmed the diagnosis of AO.

Correspondence: Serdar Aslan MD, Giresun University Faculty of Medicine, Department of Radiology, Giresun, Turkiye

Phone: +90 5448852276 E-mail: serdaraslan28@hotmail.com ORCID-ID: orcid.org/0000-0003-2950-8767

Received: 08.06.2019 Accepted: 31.07.2019

Cite this article as: Aslan S, Nural MS. A Rare Cause of Adrenal Mass: Adrenocortical Oncocytoma. J Urol Surg 2019;6(4):335-338.

๑Copyright 2019 by the Association of Urological Surgery / Journal of Urological Surgery published by Galenos Publishing House. 


\section{Case Report}

A 46-year-old female patient was referred to our clinic by a urologist for ultrasonography (US) and suspicion of renal stone due to pain in the left side of the abdomen. Physical examination revealed tenderness in the left upper quadrant. Her history was unremarkable. Serum electrolytes, blood urea nitrogen, creatinine, complete blood count and urinalysis were within the normal ranges. Renal US showed no left kidney stone, but a hypoechoic solid mass was observed in the left adrenal gland with a smooth, heterogeneous internal structure measuring 50x45 mm. A triphasic contrast-enhanced computed tomography (CT) was performed to characterize the detected mass. Contrast-enhanced CT showed a smooth, heterogeneous solid mass measuring $52 \times 45 \mathrm{~mm}$. In the first phase without contrast, the mass density was found to be 33 Hounsfield units (HU) and it was $71 \mathrm{HU}$ of the 70 seconds after contrast medium (CM) administration (venous phase) and, it was $64 \mathrm{HUs}$ 15 minutes after CM administration (late phase) (Figure $1 \mathrm{a}, \mathrm{b}$, c). Relative percentage washout (RPW) was calculated as 9.8\%, absolute percentage washout (APW) was 18.4\% and the mass was interpreted as non-adenoma lesion. Capsule irregularity, fatty tissue invasion, or lymphadenopathy was not detected. Further diagnostic workup did not reveal hypertension, headache, palpitation or inappropriate perspiration; in addition, the levels of adrenocortical hormones were normal. Since malignancy could not be ruled out by the imaging findings, the patient was referred to surgery, and laparoscopic adrenalectomy was performed. No major bleeding or hemodynamic instability events were encountered perioperatively. The mass was completely removed. Microscopic examination revealed large amounts of polygonal cells, eosinophilic cytoplasm and minimal mitotic figures (Figure 2). Immunohistochemical examination showed positive staining for vimentin, synaptophysin and melan- $A$, and negative staining for chromogranin (Figure 3). In the electron microscopy examination, the cells contained a large amount of mitochondria, and the number of other organelles was low. As a result of histopathological evaluation using the Lin-Weiss-Bisceglia system, the diagnosis was confirmed as benign $\mathrm{A} 0$. There was no recurrence in one-year follow-up. Written informed consent was obtained from the patient.

\section{Discussion}

Adrenal incidentaloma is defined as benign neoplasia, which is incidentally found in radiological imagng and not causing clinical and hormonal abnormalities and larger than $1 \mathrm{xm}$ in diameter (5). A0 which is a rare cause of adrenal incidentaloma, can be seen in all ages. AO more commonly occur in the left adrenal gland (left/right ratio=3.5:1), and in women (female/ male ratio $=2.5: 1)(6)$. Although they are considered to be nonfunctional, $31 \%$ of AOs are hormonally active according to the latest literature. The most common clinical manifestations of hormonally active AOs have been reported to be hypertension, Cushing's syndrome and virilization (3). Interleukin 6 and aldosterone-secreting AO cases have also been reported. (7). In our case, the mass was not hormonally active.

The imaging features of AOs are not typical, thus it is difficult to establish a preoperative diagnosis. AOs are frequently encapsulated with smooth neoplasms that reach a size large larger than $4 \mathrm{~cm}$. CT and magnetic resonance imaging may show central necrosis of varying degrees, but no imaging features are reliable in distinguishing $\mathrm{AO}$ from other adrenal masses and benign $\mathrm{AO}$ s from malign $\mathrm{AOs}$ (8). On non-contrast $\mathrm{CT}$, the density

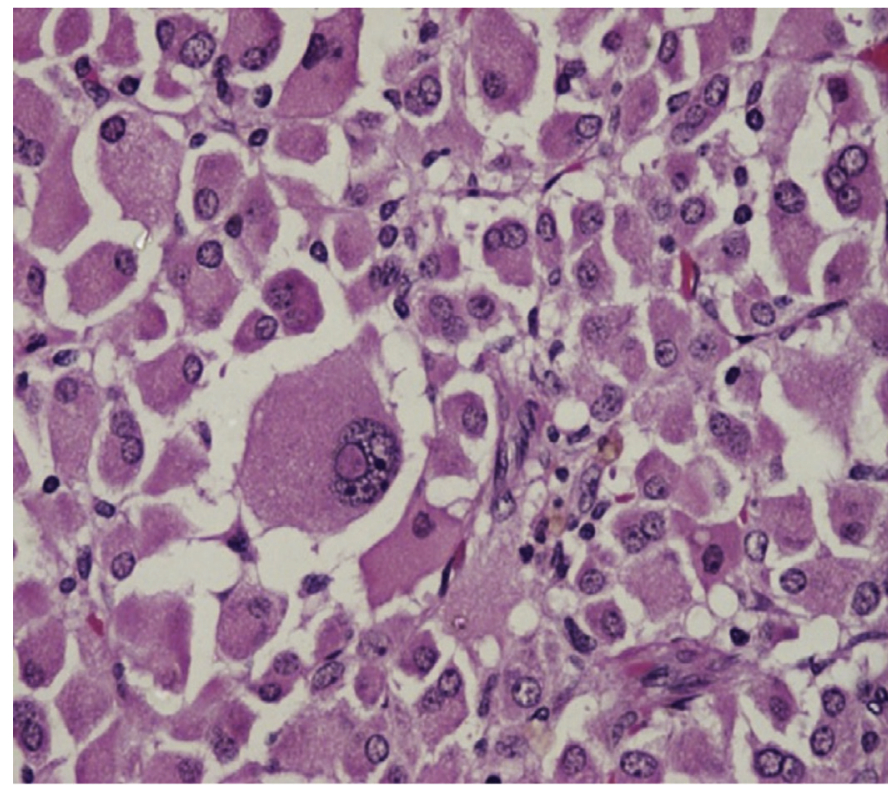

Figure 2. Haematoxylin-eosin staining of the tumor shows characteristic of the presence of abundant eosinophilic cytoplasm

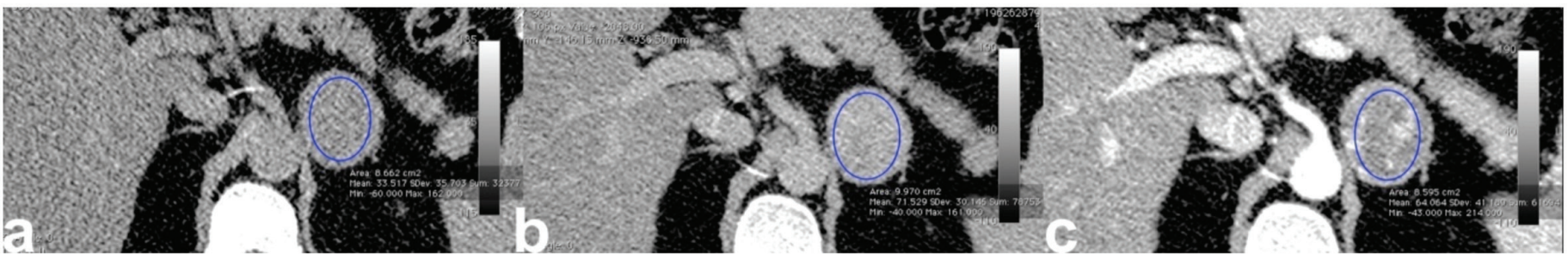

Figure 1. Axial computed tomography images show left adrenal tumor measuring $52 \times 45 \mathrm{~mm}$. Non-contrast images a), the mass density was found to be 33 Hounsfield units (HU), 70 seconds (venous phase) b) was $71 \mathrm{HU}, 15$ minutes (late phase) c) was $64 \mathrm{HU}$ 


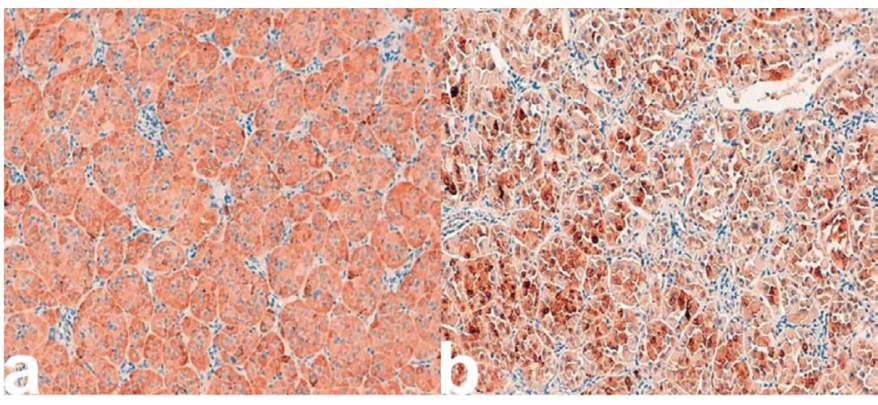

Figure 3. Immunohistochemical studies shows positive staining for melan-A a) and synaptophysin b). Tumor was considered benign according to the LinWeiss-Bisceglia criteria

of $\mathrm{AO}$ is above $10 \mathrm{HU}$. It shows non-homogenous contrast enhancement in dynamic contrast-enhanced CT. AO shows a slow washout in contrast to benign lesions. RPW is below $40 \%$ and APW is below $60 \%$. It may show similar imaging properties with pheochromocytomas and adrenocortical carcinomas. In our case, the mass was larger than $4 \mathrm{~cm}$. There was no capsule irregularity, no fatty tissue invasion or lymphadenopathy. The density of the mass was measured as $33 \mathrm{HU}$ on the non-contrast CT images RPW was calculated as $9.8 \%$ and APW was $18.4 \%$ and the mass was interpreted as non-adenoma lesion and the patient was refered for surgery.

The surgical treatment of $\mathrm{AO}$ has been traditionally involving open surgical approach depending on tumor size and function. However, recent advances in endoscopic methods have led to an increase in the number of laparoscopic adrenalectomies performed. Studies comparing the open approach with laparoscopic approach have shown that laparoscopic approach has less morbidity, faster recovery, and shorter hospital stay (9). However, there are controversies about laparoscopic resection of tumors larger than $6 \mathrm{~cm}$ and/or potentially malignant tumors (10). The biggest concern in this subject is the idea that laparoscopic surgery may cause an increase in the risk of recurrence in large tumors and cause residual tumor tissue. However, the general idea is that laparoscopic surgery can be performed safely if no adipose tissue invasion or lymphadenopathy is detected. In our case, no evidence of adipose tissue invasion was detected on the preoperative CT images, and the tumor was completely removed by laparoscopic surgery.

The diagnosis of $\mathrm{AO}$ is mainly based on histological and immunohistochemical examination. Oncocytomas are characterized by a typical gross dark brown color. Tumor cells have abundant eosinophilic and granular cytoplasm, rarely have a pleomorphic nuclei or a mitotic figure. A small amount of lymphocyte infiltration may be seen in the interstitium. Electron microscopy examinations show tumor cells containing abundant mitochondria (11). It is very difficult to determine the immunohistochemical profiles of AO's, since immunohistochemical studies were not performed in all cases reported in the literature and the same staining pattern was not used in the cases. In the literature, it is reported that AOs are negative for S-100 and chromogranin and positive for melan-A staining. Although positive staining for inhibin is often reported, positive staining for synaptophysin is rare. Vimentin staining has been reported in most cases $(12,13)$. In our case, similar to the literature, immunohistochemical examination showed positive staining for vimentin, synaptophysin and melan- $A$, and negative staining for chromogranin.

Most AOs are benign. However, it is known that 20\% have malign potential (3). Therefore, accurate classification of AO is important. The Lin-Weiss-Bisceglia system is used for classification. This system includes the following major criteria: a mitotic rate of more than 5 mitoses per $50 \mathrm{HPF}$, any atypical mitoses or venous invasion. The minor criteria include large size (>10 cm and/or $>200 \mathrm{~g}$ ), necrosis, capsular invasion or sinusoidal invasion and definitional criteria include predominantly cells with eosinophilic granular cytoplasm, high nuclear grade and diffuse architectural pattern. The presence of any one of the major criteria, indicates malignancy one or more of the minor criteria is considered malignant potential. Absence of the major and minor criteria indicates benign tumor. In our case, the tumor did not meet any of the major and minor criteria and was evaluated as benign $\mathrm{A} 0$. No recurrence was observed during a 1-year follow-up.

In conclusion, AO is one of the rare causes of adrenal incidentalomas. Imaging methods are unable to distinguish from malign adrenal masses, and definitive diagnosis is possible with histopathological examinations. Therefore, adrenalectomy is the basis of treatment. Although AOs have malign potential or malign subtypes, it is usually benign in character. However, long-term follow-up is recommended because there is no clear evidence in the literature about the real potential of AOs.

\section{Ethics}

Informed Consent: Written informed consent was obtained from the patient.

Peer-review: Externally peer-reviewed.

\section{Authorship Contributions}

Concept: S.A., M.S.N., Design: S.A., M.S.N., Data Collection and/ or Processing: S.A., M.S.N., Analysis and/or Interpretation: S.A., M.S.N., Literature Research: S.A., M.S.N., Writing: S.A.

Conflict of Interest: No conflict of interest was declared by the authors.

Financial Disclosure: The authors declared that this study received no financial support. 


\section{References}

1. Mansmann G, Lau J, Balk E, Rothberg M, Miyachi Y, Bornstein SR. The clinically inapparent adrenal mass: update in diagnosis and management. Endocr Rev 2004;25:309-340.

2. Kakimoto $S$, Yushita $Y$, Sanefuji $T$, Kondo A, Fujishima $N$, Kishikawa $M$, Matsumoto K. Non-hormonal adrenocortical adenoma with oncocytomalike appearances [J]. Hinyokika Kiyo 1986;32:757-763.

3. Wong DD, Spagnolo DV, Bisceglia M, Havlat M, McCallum D, Platten MA. Oncocytic adrenocortical neoplasms-a clinicopathologic study of 13 new cases emphasizing the importance of their recognition. Hum Pathol 2011:42:489-499.

4. Lee SS, Baek KH, Lee YS, Lee JM, Kang MI, Cha BY, Lee KW, Son HY, Kang SK. Subclinical Cushing's syndrome associated with an adrenocortical oncocytoma. J Endocrinol Invest 2008;31:675-679.

5. Young WF Jr. Clinical practice. The incidentally discovered adrenal mass. N Engl J Med 2007;356:601-610.

6. Mearini L, Del Sordo R, Costantini E, Nunzi E, Porena M. Adrenal oncocytic neoplasm: a systematic review. Urol Int 2013;91:125-133.

7. Kawahara Y, Morimoto A, Onoue A, Kashii Y, Fukushima N, Gunji Y. Persistent fever and weight loss due to an interleukin-6-producing adrenocortical oncocytoma in a girl-review of the literature. Eur J Pediatr 2014;173:11071110.

8. Tirkes $T$, Gokaslan $T$, McCrea J, Sandrasegaran $K_{1}$, Hollar MA, Akisik $F_{1}$ Lall C. Oncocytic neoplasms of the adrenal gland. AJR Am J Roentgenol 2011;196:592-596.

9. Smith $\mathrm{CD}$, Weber $\mathrm{CJ}$, Amerson JR. Laparoscopic adrenalectomy: new gold standard. World J Surg 1999;23:389-396.

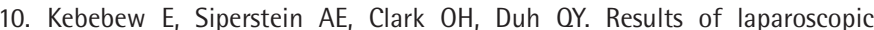
adrenalectomy for suspected and unsuspected malignant adrenal neoplasms. Arch Surg 2002;137:948-953.

11. Seo IS, Henley JD, Min KW. Peculiar cytoplasmic inclusions in oncocytic adrenal cortical tumors: an electron microscopic observation. Ultrastruct Pathol 2002;26:229-235.

12. Bisceglia M, Ludovico O, Di Mattia A, Ben- Dor D, Sandbank J, Pasquinelli G, Lau SK, Weiss LM. Adrenocortical oncocytic tumors: report of 10 cases and review of the literature. Int J Surg Pathol 2004;12:231-243.

13. Nguyen GK, Vriend R, Ronaghan D, Lakey WH. Heterotopic adrenocortical oncocytoma. A case report with light and electron microscopic studies. Cancer 1992;70:2681-2684. 